\title{
Eğitimli Gençlerin Benlik Saygısı ile Kadına Yönelik Şiddete Karşı Tutumları
}

Arasındaki ilişki*

\author{
The Relationship Between The Self-esteem of Educated Young People and Attitudes towards Violence
}

Against Women

\author{
Leyla Delibaşi, Filiz Polatii, ỉbrahim Biliriii, Aynur Ekren ${ }^{\mathrm{iv}}$, Semra Çelikliv
}

'Dr.Öğr.Üyesi, Hasan Kalyoncu Üniversitesi Meslek Yüksekokulu Diyaliz Bölümü, https://orcid.org/0000-0002-9529-5459

iiDr.Öğr.Üyesi, Osmaniye Korkut Ata Üniversitesi Sağlık Bilimleri Fakültesi Ebelik Bölümü, https://orcid.org/0000-0001-8326-9504

iiiAraş.Gör., Hasan Kalyoncu Üniversitesi Sağlık Bilimleri Fakültesi Hemşirelik Bölümü, https://orcid.org/0000-0002-0110-3867

ivÖğr.Gör., Hasan Kalyoncu Üniversitesi Meslek Yüksekokulu Diyaliz Bölümü, https://orcid.org/0000-0001-7502-0266

vDr.Öğr.Üyesi, Hasan Kalyoncu Üniversitesi Meslek Yüksekokulu IIlk Ve Acil Yardım Bölümü, https://orcid.org/0000-0002-4763-1059

Öz

Amaç: Bu araştırma, eğitimli gençlerin benlik saygısı ile kadına yönelik şiddete karşı tutumları arasındaki ilişkinin belirlenmesi amacıyla yapılmıştır.

Yöntem: Tanımlayıcı olarak gerçekleştirilen araştırmanın örneklemini Hasan Kalyoncu Üniversitesi Meslek Yüksekokulu’nda öğrenim gören 437 öğrenci oluşturmuştur. Veriler 4-10 Mart 2019 tarihlerinde toplanmıştır. Verilerin toplanmasında Sosyo-Demografik Bilgi Formu, Rosenberg Benlik Saygısı Ölçeği Kısa Form (RBS-10) ve Kadına Yönelik Şiddet Tutum Ölçeği (iSKEBE) kullanılmıştır. Verilerin analizinde sayı, yüzdelik, ortalama, ki-kare, korelasyon analizi kullanılmıştır.

Bulgular: Araştırmaya katılanların \%66,8'inin kadın, \%87,2'sinin gelirinin giderine denk olduğu, \%20,4'ünün adalet bölümünde öğrenim gördüğü, \%71,4'ünün aile içi sorunlarda anne babasının birlikte karar verdiği, \%18.1'inin babasının yalnız karar verdiği, $\% 12,4^{\prime}$ ünün bu güne kadar en az bir defa şiddete maruz kaldığı belirlenmiştir. Araştırmaya katılan kadınların \%60,3'ü ve erkeklerin $\% 44,1^{\prime} i$ kadına yönelik şiddeti önlemede kanunların yeterli düzeyde mevcut olmadığını; kadınların \%67,1'i ve erkeklerin \%49,7'si şiddeti önleme yöntemlerinin yeterli olmadığını ifade etmişlerdir $(p<0,0,05)$. Öğrencilerin şiddete ilişkin tutum ölçeği genel puan ortalamasına $(122,60 \pm 22,3)$ göre şiddete karşı geleneksellikten uzak ve çağdaş bir görüşe eğilimli oldukları aynı zamanda benlik saygısı yüksek olan öğrencilerin şiddete karşı $(r=0,118, p<0.05)$ bir tutum gösterdikleri belirlenmiştir.

Sonuç: Benlik saygısı yüksek olan eğitimli gençlerin, kadına yönelik şiddete karşı oldukları saptanmıştır.

Anahtar Kelimeler: Kadına yönelik şiddet, benlik saygısı, eğitimli gençler, tutum

\section{ABSTRACT}

Aim: The aim of this study was to determine the relationship between educated youth's self-esteem and attitudes towards violence against women.

Methods:Thesample of the descriptive study consisted of 437 students studying at Hasan Kalyoncu University Vocational School. Data were collected between4-10 March 2019, and the Socio-Demographic Information Form, Rosenberg Self-Esteem Scale Short Form (RBS-10) and Violence Against Women Scale (ISKEBE) were used to collect the data. Number, percentage, mean, chi-square, correlation analysis were used for data analysis.

Results: $66,8 \%$ of the respondents were women, $87,2 \%$ were equivalent to in come, $20,4 \%$ were educated in the justice department, $71,4 \%$ were decided by their parents in family problems, $18,1 \%$ were their father's. $12,4 \%$ of them have been subjected to violence at least once. $60,3 \%$ of the women and $44,1 \%$ of the men stated that there are no laws to prevent violence against women; $67,1 \%$ of the women and $49,7 \%$ of the men stated that the ones preventing violence were not enough $(p<0,05)$. According to the average score of the attitude scale of the students $(122,60 \pm 22,3)$, it is determined that students have a tendency towards a traditional and unconventional attitude towards violence and students who have high self-esteem $(r=0,118, p<0,05)$.

Conclusions: It is determined that educated young people with high self-esteem are against violence against women.

Keywords: Violence against women, self esteem, educated youth, attitude

*Lokman Hekim Dergisi, 2020; 10 (2): 222-230

DOI: $10.31020 /$ mutftd.667795

e-ISSN: $1309-8004$

Geliş Tarihi-Received: 30 Aralık 2019; Kabul Tarihi - Accepted: 18 Nisan 2020

iletişim - Correspondence Author: Filiz Polat <filizmermer@yahoo.com> 


\section{Giriş}

Türk Dil Kurumu'na göre benlik kelimesi; "Bir kimsenin öz varlığı, kişiliği, onu kendisi yapan şey, kendilik, şahsiyet, kendi kişiliğine önem verme" olarak tanımlanmıştır. ${ }^{1}$ Benlik saygısı bireyin kendini nasıl hissettiği, nasıl algıladığı ile ilgilidir. Kişinin kendisini olumlu-olumsuz veya değerli-değersiz bulmasıyla ilgili hissettiğidir. Benlik saygısı da kişinin, kendi hakkındaki düşünceleri ve kendini nasıl hissettiği ile ilgili yaptığı içsel değerlendirmesini ifade eden bir durumdur. ${ }^{2,3,4,5}$

Benlik saygısının oluşması çocukluk çağında başlayıp, özellikle ergenlik döneminde şekillenen, yaşam boyu öğrenme ve geliştirme ile devam eden bir durumdur. ${ }^{2,6}$ Benlik saygısının gelişmesinde, kişinin kendini önemli hissetmesi, yeteneklerini gösterebilmesi, bilgi birikimini ve becerilerini ortaya koyabilmesi, başarılı olabilmesi, toplum içinde kabul görmesi ve beğenilmesi gibi etkenler önemli rol oynamaktadır. ${ }^{3,4}$ Sağlıklı benlik saygısına sahip kişiler, kendine güvenen, yaptıklarının sorumluluğunu alan, gerçekçi hedefleri olan, kendini yönetebilen, kendini diğer kişilerden daha az değerli hissetmeyen, kendinden memnun olan, kendi ile ilgili kararları verebilen ve tutarlı bir şekilde devam ettirebilen sağııkı ve enerjik olarak nitelenmektedir., ${ }^{3,4}$ Sağlıksız ya da zayıf benlik saygısına sahip kişiler ise; kendilerini önemsemeyen, kendilerini çaresiz ve değersiz hisseden, kendini başarısız ve beceriksiz gören, enerjilerini kaybetmiş ve kendini yönetemeyen kişilerdir. ${ }^{3,4}$

Bireylerin benlik saygısının yüksek olması ile sağııkı bireyler, aileler yetişmekte ve dolayısıyla sağlıkı ailelerden oluşan bir toplum oluşabilmektedir. Toplumun çekirdeği olan ailede bireylerin benlik saygısının yüksek olması, onların gelecekte kişisel veya sosyal yaşamlarında, aile veyayabancı kişiler tarafından maruz kalabilecekleri her türlü şiddet eylemlerine karşı güçlü yetişmelerini sağlayacaktır. Kendilerinin yanı sıra diğer insanlara da uygulanan şiddete karşı bir tutum oluşturmalarına sebep olacaktır. Bu sebeple kadına yönelik şiddetin önlenebilmesinde, toplumda yetişen bireylerin benlik saygılarının yüksek olması gerekmektedir. $^{7}$

Kadına yönelik şiddet, her kültürde ve yaşta toplumun ekonomik, sosyal, eğitim ve sağlık alanlarını etkileyen, evrensel olarak bütün dünyada uygulanan bir insan hakkı ihlalidir. Kadına şiddet coğrafi bölge ayırt etmeksizin, öğrenim düzeyi ve ekonomik durum fark etmeden, tüm dünyada görülebilen bir halk sağlığı sorundur..$^{8,9,10,12}$ Şiddet tüm dünya da olduğu gibi ülkemizde de çok ciddi bir evrensel sorun olup gün geçtikçe de artan bir sorun olmaya devam etmektedir. ${ }^{8}$ Ülkemizde ve dünyada her geçen gün kadına yönelik şiddetin arttığı gözlenmiştir. Aile içi şiddete en fazla en fazla kadınlar ve kız çocukları maruz kalmakta ve fiziksel, cinsel, duygusal, ekonomik, sosyal açıdan çok ciddi şekilde etkilenmektedirler. ${ }^{9,10,11}$ Kadını baskı altında tutmayı amaçlayan kadına yönelik şiddet cinsiyet temelli olarak gerçekleştirilen, öncelikli olarak mücadele edilmesi gereken toplumsal sorumluluklardan birisidir. Kadına yönelik olarak temel hak ve özgürlüklerin ihlali olan kadına yönelik şiddet, erkekler ve kadınlar arasındaki güç ilişkilerinin eşit olmayan sonucu olarak ortaya çıkan önemli bir sorundur. ${ }^{13,14}$

Yapılan çalışmalarda; çocukken şiddete tanık olunması veya maruz kalınması, izlenen film ve dizilerin şiddet içerikli olması, eğitim ve sosyoekonomik düzeyin düşük olması, eşin alkol ve uyuşturucu madde kullanması, çevrenin ve ailenin şiddeti normal sayması ve bazı durumlarda şiddeti desteklemesi, partnerin kişilik bozukluğu veya depresyonda olması gibi faktörlerin şiddet eğilimini artırdığı belirtilmektedir. ${ }^{15,16}$ Şiddet gören kişiler duygusal, psikolojik, fiziksel ve sosyal açıdan çok ciddi bir şekilde etkilenmektedir. Şiddete maruz kalan kişilerde benlik saygısı daha düşük olmakta ve fiziksel yaralanmalar, ilaç-alkol kullanımında artış, depresyon, kabus görme, uykusuzluk, güven duygusunda azalma, üzüntülü ve öfkeli hissetme, mutsuz hissetme, kendilerini sosyal ortamlardan izole etme, anksiyete ve intihar gibi durumlar görülebilmektedir. ${ }^{8,9,10,17,18}$ 
Bazı toplumlarda ile içinde kadına şiddet bir terbiye aracı olarak görülmekte, kabul edilebilir bir davranışmış gibi empoze edilmekte ve 'aile içinde yaşanan sorunlar aile içinde kalır' gibi söylemlerle kadınlar susturularak şiddet görmeye devam etmektedirler. ${ }^{19,20}$ Yapılan çalışmalarda benlik saygısı düşük olan erkeklerin benlik saygısı yüksek olan erkeklere oranla şiddete karşı geleneksel bir yaklaşımda olup şiddete meyilli oldukları gözlenmiştir. ${ }^{20}$

\section{Amaç ve Önem}

Bu araştırma, eğitimli gençlerin benlik saygısı ile kadına yönelik şiddete karşı tutumları arasındaki ilişkinin belirlenmesi amacıyla planlanmıştır. Bu çalışma ile geleceğin yetişkin bireyleri olan gençlerimizin şiddet olgusuna yönelik kendilerini değerlendirmelerine fırsat verilmesinin önemli olduğu düşünülmektedir. Bu bağlamda kadına yönelik şiddeti engelleyecek eğitim ve uygulamaların düzenlenmesinin önemli olduğu düşünülmektedir.

\section{MATERYAL METOD}

Araştırmanın Tipi: Araştırma tanımlayıcı olarak tasarlandı.

Araştırmanın Yeri ve Zamanı: Araştırma, 4-10 Mart 2019 tarihleri arasında Hasan Kalyoncu Üniversitesi Meslek Yüksekokulu'nda yapıldı.

Araştırmanın Evreni ve Örneklemi: Araştırmanın evrenini 2018-2019 eğitim ve öğretim yılında Hasan Kalyoncu Üniversitesi Meslek Yüksekokulu ilk ve Acil Yardım, Diyaliz, Adalet ve Anestezi bölümlerine devam eden 480 öğrenci, örneklemini ise araştırmaya katılmayı kabul eden 437 öğrenci ile yürütülmüştür. Araştırmada örneklem seçimine gidilmeyerek evrenin tamamına ulaşılmaya çalışıldı.

\section{Veri Toplama Araçları}

Araştırma verileri, araştırmacılar tarafından oluşturulan Kişisel Bilgi Formu, Rosenberg Benlik Saygısı Ölçeği Kısa Form (RBS-10), Kadına Yönelik Şiddet Tutum Ölçeği (iSKEBE) kullanılarak toplandı.

Kişisel bilgi formu: Öğrencilerin yaş, cinsiyet, medeni durum, okuduğu bölüm, anne baba eğitim durumu ve aile içi ilişkiler gibi bilgileri içeren 18 maddelik bir formdur.

Rosenberg Benlik Saygısı Ölçeği Kısa Form (RBS-10): Benlik saygısı düzeyini ölçmek için Rosenberg tarafından 1965'de geliştirilen ölçek Çuhadaroğlu tarafından 1986'da Türkçe'ye uyarlanmıştır. Ölçek "çok doğru", "doğru", "yanlış", "çok yanlış" olmak üzere dört seçenek üzerinden değerlendirilen 10 maddeden oluşmaktadır. Ölçeğin Türkçe formu için yapılan güvenirlik çalışmasında, test-tekrar test güvenirlik katsayısının 0,48 - 0,79 arasında değiştiği bulunmuştur. Ölçekten elde edilebilecek puanlar 10 ile 40 arasında değişmekte ve puan arttıkça benlik saygısının arttığını göstermektedir. ${ }^{21}$ Çalışmamızda bu ölçek için Cronbach's alpha katsayısı 0,89 bulunmuştur.

Kadına Yönelik Şiddet Tutum Ölçeği (iSKEBE Tutum Ölçeği): Kanbay tarafından 2016 yılında geliştirilmiş ve ölçeğin en az ilkokul mezunu 15-65 yaş arası bireylerde uygulanabileceği belirtilmiştir. Ölçek 'bedene yönelik tutumlar" ve "kimliğe yönelik tutumlar" olmak üzere iki alt boyut ve toplam 30 sorudan oluşmaktadır. Ölçekte puanların yüksekliği bireylerin kadına şiddete karşı olduğunu, puanın düşük olması ise kadına yönelik şiddete karşı olmadığını göstermektedir. Ölçekten 90 puanın üzerinde alan bireylerin kadına şiddete karşı olduğu, 90 puanın altında olanların ise kadına şiddete karşı olmadığı şeklinde yorumlanmaktadır. Ölçeğin Cronbach's alpha değeri 0,86 olarak belirlemiştir. ${ }^{22}$ Çalışmamızda ölçek toplam Cronbach's alpha 0,949, bedene yönelik alt boyutunda Cronbach's alpha 0,953, kimliğe yönelik alt boyutunda Cronbach's alpha katsayısı 0,910 bulunmuştur. 


\section{Verilerin değerlendirilmesi}

Araştırmada elde edilen verilerin analizi için SPSS 21,0 (Statistical Packet for Social Sciences for Windows) istatistik paket programı kullanıldı. Verilerin analizinde sayı, yüzdelik, ortalama, ki-kare, pearson korelasyon analizi kullanıldı. Ölçeklerin güvenilirliği için Cronbach's alpha katsayısı hesaplandı. Araştırmamızdan elde edilen sonuçlar $p<0,05$ anlamlılık düzeyinde değerlendirildi.

\section{Araştırmanın etik yönü}

Araştırmanın yapılabilmesi için Hasan Kalyoncu Üniversitesi Sağlık Bilimleri Fakültesi Girişimsel Olmayan Araştırmalar Etik Kurulu'ndan etik kurul izni (Karar No:2019/11; Tarih: 19.02.2019) veHasan Kalyoncu Üniversitesi Meslek Yüksek Okulu Müdürlüğü’nden kurum izni alındı. Öğrencilere anket uygulamadan önce araştırma hakkında bilgi verildi, bilgilendirilmiş onam formu okunduktan sonra araştırmaya katılmayı kabul ettiklerine dair sözel onamları alındı. Araştırmaya katılmaya gönüllü olan öğrencilere anket uygulandı.

\section{BULGULAR}

Araştırmaya katılanların yaş ortalamasının $20,63 \pm 2,5$ olduğu, $\% 66,8^{\prime}$ inin kadın, \%30,9'unun ilk ve acil yardım, 26,1'inin anestezi, \%22,7'sinin diyaliz, \%20,4'ünün adalet bölümü öğrencisi olduğu, \%87,2' sinin gelirinin giderine denk olduğu belirlenmiştir. Anne baba eğitim durumları incelendiğinde; annelerin \%46,7'sinin ortaöğretim, \%35,9'unun ilköğretim mezunu, babaların \%51,3'ünün ortaöğretim, \%25,6'sının ilköğretim, \%22,7'sinin üniversite mezunu olduğu belirlenmiştir. Katılanların \%71,4'ü aile içi sorunlarda anne ve babasının birlikte karar verdiğini, \%18,1'i babasının yalnız karar verdiğini; \%65,2'si eğitim öğretim konularında anne babasının ortak karar verdiğini, \%16,7'si babasının karar verdiğini; \%51'i parasal sorunlarda anne babasının ortak karar verdiğini, \%40,7'si babasının karar verdiğini belirtmiştir. Öğrencilerin $\% 46,5^{\prime}$ i aile ilişkilerini çok iyi, \%41,2'si iyi, \%10,3'ü orta olarak tanımlamış, \%12,4'ü bu güne kadar en az bir defa aile içinde şiddete maruz kaldığını belirtmiştir (Tablo 1).

Tablo 1. Öğrencilerin Sosyodemografik Özellikleri

\begin{tabular}{lll}
\hline & Sayı (n:437) & $\%$ \\
\hline Cinsiyet & 292 & 66,8 \\
Kadın & 145 & 33,2 \\
Erkek & & \\
Bölüm & 114 & 26,1 \\
Anestezi & 99 & 22,7 \\
Diyaliz & 135 & 30,8 \\
Ilk ve Acil Yardım & 89 & 20,4 \\
Adalet & & \\
Anne Eğitim Düzeyi & 39 & 8,9 \\
Okur Yazar Değil & 157 & 35,9 \\
Illköğretim & 207 & 46,7 \\
Ortaöğretim & 37 & 8,5 \\
Üniversite & & \\
Baba Eğitim Düzeyi & 2 & 0,5 \\
Okur Yazar Değil & 112 & 25,5 \\
Ilköğretim & 224 & 51,3 \\
Ortaöğretim & 99 & 22,7 \\
Üniversite & & \\
Ekonomik Düzey & 6 & 11,4 \\
Gelir Giderden Az & 381 & 87,2 \\
Gelir Gidere Denk & 50 & \\
Gelir Giderden Fazla & &
\end{tabular}


Tablo 1. Öğrencilerin Sosyodemografik Özellikleri (devamı)

\begin{tabular}{|c|c|c|}
\hline & Sayı (n:437) & $\%$ \\
\hline \multicolumn{3}{|c|}{ Aile İçi Sorunlarda Kimin Sözü Geçer? } \\
\hline Anne & 31 & 7,1 \\
\hline Baba & 79 & 18,1 \\
\hline Anne-Baba & 312 & 71,4 \\
\hline Diğer (Büyükanne, Dede Vb,) & 15 & 3,4 \\
\hline \multicolumn{3}{|c|}{ Eğitim Öğretim Konularında Kimin Sözü Geçer? } \\
\hline Anne & 44 & 10,1 \\
\hline Baba & 73 & 16,7 \\
\hline Anne-Baba & 285 & 65,2 \\
\hline Diğer (Büyükanne, Dede Vb.) & 35 & 8,0 \\
\hline \multicolumn{3}{|c|}{ Parasal Sorunlarda Kimin Sözü Geçer? } \\
\hline Anne & 29 & 6,6 \\
\hline Baba & 178 & 40,7 \\
\hline Anne-Baba & 223 & 51,1 \\
\hline Diğer (Büyükanne, Dede Vb.) & 7 & 1,6 \\
\hline \multicolumn{3}{|c|}{ Aile İçi İlişkilerinizi Nasıl Tanımlarsınız? } \\
\hline Kötü & 9 & 2,1 \\
\hline Orta & 45 & 10,3 \\
\hline İyi & 180 & 41,2 \\
\hline Çok İyi & 203 & 46,4 \\
\hline \multicolumn{3}{|c|}{ Aile İçinde Şiddete Maruz Kaldınız Mı? } \\
\hline Evet & 54 & 12,4 \\
\hline Hayır & 383 & 87,6 \\
\hline \multirow[t]{2}{*}{ Yaş } & Min-Max & $\mathrm{X} \pm \mathrm{SD}$ \\
\hline & $18-43$ & $20,63 \pm 2,5$ \\
\hline
\end{tabular}

Öğrencilerin ISKEBE toplam puan ortalaması 122,60 22,3 , iSKEBE bedene yönelik alt boyut puan ortalaması $72,7 \pm 11,8$, iSKEBE kimliğe yönelik alt boyut puan ortalaması $49,8 \pm 13,1$ ve RBS toplam puan ortalaması 32,0 $\pm 4,6$ olarak bulunmuştur (Tablo 2).

Tablo 2. Rosenberg Benlik Saygısı Ölçeği İle iSKEBE Kadına Yönelik Şiddet Tutum Ölçeği Toplam ve Alt Boyut Puan Ortalamaları (n=437)

\begin{tabular}{lll}
\hline Ölçek Puanları & Min-Max & X \pm SD \\
\hline ISKEBE Toplam Puan & $38-150$ & $122 \pm 22,3$ \\
iSKEBE Bedene Yönelik Alt Boyut & $16-80$ & $72,7 \pm 11,8$ \\
iSKEBE Kimliğe Yönelik Alt Boyut & $15-70$ & $49,8 \pm 13,1$ \\
RBS Toplam Puan & $17-40$ & $32,0 \pm 4,6$ \\
\hline
\end{tabular}

RBS=Rosenberg Benlik Saygısı Ölçeği, iSKEBE=Kadına Yönelik Şiddet Tutum Ölçeği

Benlik saygısı ile kadına yönelik şiddet tutumu arasında pozitif yönlü bir ilişki belirlenmiştir $(r=0,118, p<0,05)$

(Tablo 3).

Tablo 3. Rosenberg Benlik Saygısı Ölçeği İle íSKEBE Kadına Yönelik Şiddet Tutum Ölçeği ve Alt Boyutları Arasındaki Illişkiye Yönelik Korelasyon Değerleri

\begin{tabular}{lll}
\hline & RBS & P Değeri \\
\hline iSKEBE & Korelasyon Katsayısı & 0,014 \\
iSKEBE Bedene Yönelik Alt Boyut & 0,118 & 0,005 \\
iSKEBE Kimliğe Yönelik Alt Boyut & 0,134 & 0,093 \\
\hline
\end{tabular}

Pearson Korelasyon Analizi, RBS=Rosenberg Benlik Saygısı Ölçeği, iSKEBE=Kadına Yönelik Şiddet Tutum Ölçeği 
Katılanlardan şiddete maruz kalanların, benlik saygılarının daha düşük olduğu, kadına yönelik şiddet ölçeğinden aldıkları puan ortalamasının daha düşük olduğu, yani gelenekselliğe daha yakın oldukları belirlenmiştir $(p<0,05)$ (Tablo 4).

Tablo 4. Aile İçinde Şiddete Maruz Kalma Durumuna Göre Rosenberg Benlik Saygısı Ölçeği ille ISKEBE Kadına Yönelik Şiddet Tutum Ölçeği Toplam ve Alt Boyut Puan Ortalamaları

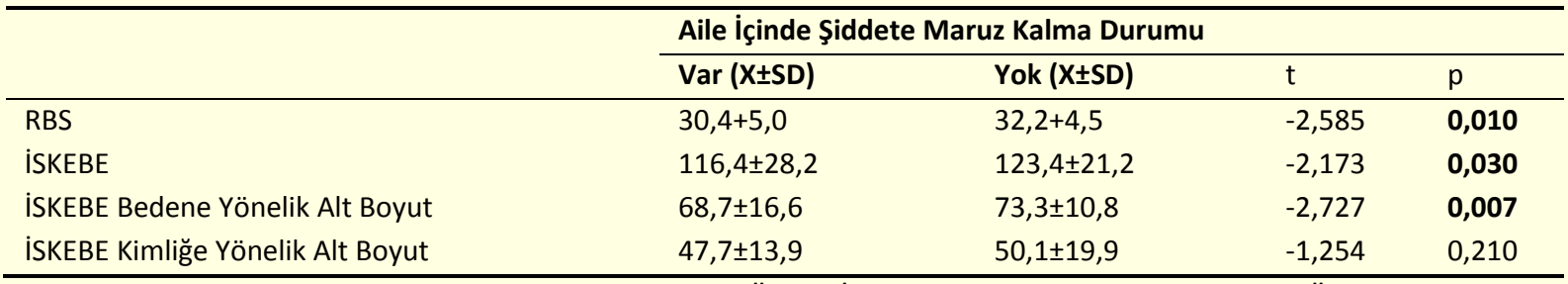

Bağımsız Gruplarda T Testi, RBS=Rosenberg Benlik Saygısı Ölçeği, ISKEBE=Kadına Yönelik Şiddet Tutum Ölçeği

Kadınların \%60,3'ü, erkeklerin \%44,1'i kadına yönelik şiddeti önlemede kanunların mevcut olmadığını; kadınların \%67,1'i, erkeklerin \%49,7'si şiddeti önlemede yapılanların yeterli olmadığını ifade etmişlerdir $(p<0,05)$ (Tablo 5).

Tablo 5. Cinsiyete Göre Gençlerin Şiddeti Önlemede Mevcut Kanunlar ve Yapılanlar Konusundaki Düşünceleri

\begin{tabular}{|c|c|c|c|c|c|}
\hline & \multicolumn{3}{|c|}{ Cinsiyet } & & \multirow[b]{3}{*}{$\mathbf{P}^{*}$} \\
\hline & \multicolumn{2}{|l|}{ Kadın } & \multicolumn{2}{|l|}{ Erkek } & \\
\hline & Sayı (n:292) & $\%$ & Sayı (n:145) & $\%$ & \\
\hline \multicolumn{6}{|c|}{ Ülkemizde Kadına Yönelik Şiddeti Önlemek İçin Kanunlar Mevcut Mu? } \\
\hline Evet & 68 & 23,3 & 51 & 35,2 & \\
\hline Hayır & 176 & 60,3 & 64 & 44,1 & 0,005 \\
\hline Bilmiyorum & 48 & 16,4 & 30 & 20,7 & \\
\hline \multicolumn{6}{|c|}{ Kadına Yönelik Şiddeti Önlemede Yapılanlar Yeterli Mi? } \\
\hline Evet & 8 & 2,7 & 16 & 11,0 & \\
\hline Hayır & 196 & 67,1 & 72 & 49,7 & 0,000 \\
\hline Kısmen & 55 & 18,8 & 31 & 21,4 & \\
\hline Fikrim yok & 33 & 11,3 & 26 & 17,9 & \\
\hline
\end{tabular}

*Ki-Kare

\section{TARTIŞMA}

Eğitimli gençlerin benlik saygısı ile kadına yönelik şiddete karşı tutumları arasındaki ilişkinin belirlenmesi amacıyla yapmış olduğumuz çalışmamızdan elde ettiğimiz bulgulara göre; öğrencilerin \%12,4'ü aile içi şiddete maruz kaldığını belirtmiştir (Tablo 1). Kanbay ve arkadaşlarının hemşirelik öğrencileri üzerinde yapmış olduğu araştırmada öğrencilerin yarısına yakını $(\% 44,1)$ yaşamının herhangi bir döneminde ebeveynlerinden şiddet gördüğünü ${ }^{23}$, Dağlar ve arkadaşlarının ebelik ve hemşirelik öğrencileri üzerinde yaptığı çalışmada öğrencilerin $\% 26,2^{\prime}$ si anne ve babasından şiddet gördüğünü ifade etmiştir. ${ }^{24}$ Çalışmamızdaki aile içi şiddete maruz kalma oranlarının Kanbay ve Dağlar'ın araştırmasından daha düşük olması; aile ortamında ve yaşanılan çevrede şiddetin olağan bir durum olarak kabul edilmesinden, ailede erkek hakimiyetinin baskın olmasından, şiddetin bazı çevrelerde terbiye yöntemi olarak görülmesinden, şiddetin sorunları çözebileceğine olan inanıştan, ailevi sorunlardan ve ailenin eğitim durumundan kaynaklanabilir. Türkiye'de aile içi şiddet kurbanlarının büyük bir kısmı kadın ve çocuklardan oluşturmakta, eğitim düzeyi düşük olan ailelerde şiddetin daha fazla görüldüğü, çocukların daha fazla risk altında olduğu çalışmalarda ortaya konmuştur. ${ }^{25,26}$

Öğrencilerin kadına yönelik şiddet tutum ölçeği puanlarına baktığımızda toplam puan ve alt boyutlarının puan ortalamalarının yüksek olduğu görülmektedir (Tablo 2). Alınan puanların bu doğrultuda olmasında; öğrencilerin anne-babalarının eğitim düzeylerinin, aile yapılarının, sosyo-ekonomik faktörlerin, kız öğrencilerin araştırmaya katıım oranlarının yüksek olmasının, öğrencilerin daha çağdaş görüşe sahip 
olmalarının, gençlerin şiddetin her türüne karşı olan tutumlarının, şiddete uğramış kadınlara yönelik sempati duymalarınınve empati kurmalarının etkisi olabilir.

Çalışmamıza katılan öğrencilerin benlik saygısı toplam puan ortalamaları, olumlu yönde yüksek olduğu görülmektedir (Tablo 2). Öğrencilerin benlik saygısının gelişmesinde; aile eğitimi, anne- baba eğitim durumu, yaşanılan çevrenin sosyo-kültürel özellikleri, aile yapısı etkili olabilir. Ebeveyn eğitiminin bireyin benlik saygısının oluşmasında olumlu bir etkisibulunmaktadır. Anne ve baba eğitim düzeyleri yükseldikçe çocuğun benlik saygısı yükselmekte ve kendine olan güveni artmaktadır. ${ }^{3}$ Ünsar ve İşveren'in öğrenciler üzerinde yapmış olduğu çalışmada ebeveynlerin eğitim düzeyleri yükseldikçe benlik saygılarının arttığı, Karadağ ve arkadaşlarının yapmış olduğu başka bir çalışmada ise; gelir düzeyi düşük olan ailenin çocuklarının benlik saygıları puan ortalamalarının çok anlamlı derecede düşük olduğu, gelirin gidere eşit olduğu ailelerin çocuklarının benlik saygısı puan ortalamalarının yüksek olduğu saptanmıştır. ${ }^{3}$ Çalışmamıza katılan öğrencilerin benlik saygısı toplam puan ortalaması ile kadına yönelik şiddet toplam puan ortalaması arasında anlamlı bir ilişkinin olduğu saptanmıştır $(p<0,05)$ (Tablo 3). Bu sonuçlara göre; benlik saygısı yüksek olan eğitimli gençlerin, kadına yönelik şiddete karşı oldukları görülmektedir. Sabancıoğulları ve arkadaşlarının hemşirelik öğrencileri ile yapmış olduğu araştırmada da benlik saygısı yüksek olan öğrencilerin şiddete karşı daha çağdaş bir tutum gösterdikleri saptanmıştır. ${ }^{19}$ Akbağ ve Barakas'ın kadınlarla yaptığı çalışmada ise, kadınların benlik saygıları arttıkça şiddete ilişkin duyarlııklarının arttığı saptanmıştır. ${ }^{15}$ Yapılan araştırmalar çalışmamızla benzer sonuçları içermektedir.

Şiddet gören kadınların benlik saygı düzeylerini belirlemek amacıyla yapılan araştırmalarda, fiziksel şiddete maruz kalan kadınların, şiddete maruz kalmayan kadınlara göre daha düşük benlik saygısına sahip olduğu gözlemlenmiştir. Kadınlarda şiddet nedeniyle meydana gelen düşük benlik saygısının, aktiviteleri üzerinde olumsuz yönde etkili olabileceği literatürde yer almaktadır. ${ }^{27}$ Clement ve arkadaşları kadınlar üzerinde yaptığı çalışmadaşiddet gören kadınların benlik saygılarının düşük olduğunu bulmuşlardır. ${ }^{28}$

Çalışmamızda aile içi şiddete maruz kalan öğrencilerin benlik saygısı ölçeği puan ortalamaları ile kadına yönelik şiddet tutum ölçeği toplam puan ortalamaları ve alt boyutlarının puan ortalamalarının, şiddete maruz kalmayan öğrencilere göre daha düşük olduğu saptanmıştır (Tablo 4). Şiddet ortamında büyüyen bireyin şiddeti normal olarak görmesi, geleneksel bakış açısına sahip olması bu farklılığın nedeni olabilir. Yapılan araştırmalarda, şiddete uğrama veya tanıklık etmenin şiddet davranışı üzerinde etkili olduğu belirtilmektedir. Şiddetin öğrenilen bir davranış olduğu ve bu yolla da gelecek nesillere taşındığı düşünülmektedir. ${ }^{19}$ Bireyin büyüdüğü aile ortamı benlik saygısı üzerinde birinci dereceden önem teşkil eder. Paylaşımcı bir aile ortamı benlik saygısı yüksek, kendine güvenen kişilerin yetişmesine olanak sağlar. ${ }^{29}$ Aile içi şiddete maruz kalma nedeniyle bireyin kendine olan güvenini yitirmesi, her an şiddete maruz kalma korkusunun çalışmamızdaki aile içi şiddete maruz kalan öğrencilerin benlik saygısı gelişimini olumsuz yönde etkilediği düşünülmektedir. Hemşirelik öğrencileriyle yapılan bir araştırmada, şiddete maruz kalma durumunun düşük benlik saygısıyla ilişkili olduğu saptanmıştır. ${ }^{19}$ Silvia ve arkadaşlarının yapmış olduğu çalışmada da düşük benlik saygısının kadına yönelik şiddetle ilişkili olduğu belirlenmiştir. ${ }^{30}$

Öğrencilerin kadına şiddeti önlemede, kanunların varlığı ve kadına şiddeti önleme konusunda yapılanların yeterli olduğunu düşünmelerinden dolayı kız ve erkek öğrenciler arasında istatistiksel olarak anlamlı farklılık görülmektedir $(p<0,05)$ (Tablo 5). Bu farklılığın, erkek öğrencilerin gelişmeleri yakından takip etmelerinden, yapılan uygulamalar konusunda farkındalık düzeylerinin yüksek olmasından ve kanunlardan haberdar olmalarından kaynaklandığı düşünülmektedir. Kız öğrencilerin olaya daha empatik yaklaşımı, hemcinslerini koruma hissinin ağır basması, gelişmeleri takip etmemesi, konu hakkında bilgi sahibi olmaması ve yapılanları yetersiz görmesi şeklinde düşünmelerinin sebebi olabilir. ${ }^{19}$ 


\section{SONUÇ VE ÖNERILER}

Araştırmadan elde edilen bulgular doğrultusunda; Benlik saygısı ile kadına yönelik şiddet tutumu arasında pozitif yönlü bir ilişki belirlenmiştir. Öğrencilerin şiddete ilişkin tutum ölçeği genel puan ortalamasına göre şiddete karşı geleneksellikten uzak ve çağdaş bir görüşe eğilimli oldukları aynı zamanda benlik saygısı yüksek olan öğrencilerin şiddete karşı bir tutum gösterdikleri belirlenmiştir. Araştırmaya katılan kadınların büyük çoğunluğu kadına yönelik şiddeti önlemede kanunların yeterli düzeyde olmadığını; kadınların yarısından fazlası, erkeklerin yarısı şiddeti önleme yöntemlerinin yeterli olmadığını belirtmişlerdir. Sağlıklı bir toplum oluşturabilmesi için, kadına yönelik şiddetin önemsenmesi ve önlenmesinin yanı sıra toplumun ve bireylerin bu konuda bilgilerinin arttırılması gerekmektedir. Kadına yönelik şiddet konusunda kongre, konferans, sempozyum gibi etkinlikler desteklenmeli ve sürekliliği sağlanmalıdır. Kadın sağlığının korunmasında ve geliştirilmesinde primer sorumluluğu olan aday sağlık çalışanlarının eğitimleri süresince şiddetle mücadele konusunda uygulama ve etkinliklerde görev almalarına imkan verilmeli, öğrencilerin öğrenimleri boyunca benlik saygılarını yükseltecek destekleyici eğitim ve uygulamalara yer verilmesi önerilmektedir. Ayrıca şiddet konusunun tüm eğitim süresince dersler içerisine entegre edilerek ya da ayrı bir ders olarak verilmesi önerilebilir.

\section{BILGi}

Bu çalışma 6. Uluslararası Multidisipliner Çalışmaları Kongresi'sinde (26-27 Nisan 2019, Hasan Kalyoncu Üniversitesi Gaziantep/TÜRKiYE) sözel bildiri olarak sunulmuştur. Yazarlar arasında çıkar çatışması bulunmamaktadır.

\section{KAYNAKLAR}

1. Türk Dil Kurumu Sözlüğü Erişim Adresi: http://sozluk.gov.tr.29.08.2019. Erişim tarihi: 15.06.2019

2. Abdulghani $\mathrm{AH}$, et al. Does self-esteem lead to high achievement of the science college's students? A study from the six health science colleges. Saudi J Biol Sci 2020; 27(2): 636-642.

3. Karadağ G, ve ark. Gaziantep Üniversitesi sağlık yüksekokulu hemşirelik öğrencilerinin benlik saygıları. Fırat Sağıık Hizmetleri Dergisi 2008; 3(7): 29-42.

4. Faccini F, Gazzillo F, Gorman BS. Guilt, Shame, Empathy, Self-Esteem, and Traumas: New Data forthe Validation of the Inter personal Guilt Rating Scale-15 Self-Report (IGRS-15s) Psychodynamic Psychiatry 2020; 48(1): 79-100.

5. Erbil N, Divan Z, Önder P. Ergenlerin benlik saygısına ailelerinin tutum ve davranışlarının etkisi. Aile ve Toplum Eğitim Kültür ve Araştırma Dergisi 2006; 10(3): 7-15.

6. Yılmaz HA. Bir derleme: Benlik kavramına ilişkin bazı yaklaşımlar ve tanımlamalar. Sosyal Bilimler Dergisi 2016; 48: 79-89.

7.Koçak BT, Ünaldı N, Seren AKH. Hemşirelik öğrencilerinin özsaygı düzeyleri ve aile içi şiddete yönelik tutumları arasındaki ilişki. Sağıık ve Hemşirelik Yönetimi Dergisi 2014; 2(1): 81-89.

8. Güler N, Tel H, Tuncay ÖF. Kadının aile içinde yaşanan şiddete bakışı. C. Ü. Tıp Fakültesi Dergisi 2005; 27(2): 51-56.

9. Kabasakal Z, Girli A. Üniversite öğrencilerinin kadına yönelik şiddet hakkındaki görüşlerinin, deneyimlerinin bazı değişkenler ve yaşam doyumu ile ilişkisi (Deü Buca Eğitim Fakültesi örneği). DEÜ SBE Dergisi 2012;14(2): 105-123.

10. Yanık A, ve ark. Kadına yönelik şiddet davranışlarının değerlendirilmesi: Türkiye'den kanıt. Electronic Journal of Vocational 2014; 104-111.

11. Ali AA, Yassin K, Omer R. Domestic violence against women in eastern Sudan. BMC Public Health 2014;14(1136):1-5.

12. Türkiye'de Kadına Yönelik Aile İçi Şiddet Araştırması. T.C. Aile ve Sosyal Politikalar Bakanlığı Kadının Statüsü Genel Müdürlüğü. Ankara: Elma Teknik Basım ve Matbaacılık, 2015;31-8.

13. Cihan Ü, Karakaya H. Kadın-erkek kavramları bağlamında şiddet ve şiddetle mücadelede sosyal hizmetin rolü. AïB̈ Sosyal Bilimler Enstitüsü Dergisi 2017; 17(4): 297-324.

14. Akkaş i, Uyanık Z. Kadına yönelik şiddet. Nevşehir Hacı Bektaş Veli Üniversitesi SBE Dergisi 2016; 6 (1): 32-42.

15. Akbağ M, Barakas R. An examination on the perception of violence and its relation to self-esteem among Turkish women. Uluslararası İnsan Bilimleri Dergisi 2010;7(2):1-14.

16. Çivi S, Kutlu R, Marakoğlu K. Thefrequency of violence against women and the factors affecting this: A study on women who applied to two primary health care centers. Gülhane Tıp Dergisi 2008; 50:110-116.

17. Ortabag $\mathrm{T}$, et al. Perspectives of young adult men regarding violence against women: A cross-sectional study fromTurkey. J FamViol 2014; 29:665-674.

18. Kelleci M, ve ark. Eş şiddetinin kadınların ruh sağlığına etkileri. Türkiye Klinikleri J MedSci 2009; 29(6):1787-1793. 
19. Sabancıogulları S, ve ark. Hemşirelik öğrencilerinin kadına yönelik şiddete ve şiddette mesleki role ilişkin tutumları, benlik saygıları ve etkileyen faktörler. Hemşirelikte Eğitim Ve Araştırma Dergisi 2016; 13(1): 35-43.

20. Sezer Ö, Sumbas E. Üniversite Öğrencilerinin çiftler arası şiddeti kabullerinin çeşitli değişkenler açısından incelenmesi. Uluslararası Sosyal Araştırmalar Dergisi 2018; 11(56): 638-649.

21. Gedik Z. Üniversite öğrencilerinde öz-duyarlık ölçeği kısa formunun psikometrik özelliklerine ilişkin bir çalışma. İstanbul Aydın Üniversitesi Dergisi 2019; 11(39):275-292.

22. Kanbay Y, ve ark. iSKEBE kadına yönelik şiddet tutum ölçeği (iskebe tutum ölçeği) geliştirme çalışması. Anadolu Psikiyatri Dergisi 2017; 18(5): 453-459.

23. Kanbay $Y$, ve ark. Hemşirelik öğrencilerinin kadına yönelik aile içi şiddetle ilgili görüş ve tutumlarının belirlenmesi. Gümüşhane Üniversitesi Sağlık Bilimleri Dergisi 2012; 1(2):107-119.

24. Dağlar G, Bilgiç D, Demirel G. Ebelik ve hemşirelik öğrencilerinin kadına yönelik şiddete ilişkin tutumları. Dokuz Eylül Üniversitesi Hemşirelik Fakültesi Elektronik Dergisi 2017; 10 (4): 220-228.

25. ỉbiloğlu AO. Aile içi şiddet. Psikiyatride Güncel Yaklaşımlar 2012; 4(2): 204-222.

26. Sinan Ö, Tosun B, Ünal N. Hemşirelik öğrencilerinin şiddete bakışı. Türkiye Klinikleri J Psychiatr Nurs-Special Topics 2017; 3(2): 108-14.

27. Çelik Z, Ekici G. Şiddet gören kadınlarda benlik saygısı, başa çıkma becerileri ve aktivite performansı arasındaki ilişki. Ergoterapi ve Rehabilitasyon Dergisi 2015; 3(3):101-108.

28. Clements CM, Sabourin CM, Spiby, L. Dysphoria and hopelessness following battering: The role of perceived control, coping, and self-esteem. Journal of family violence 2004. 19(1), 25-36.

29. Tözün M. Benlik saygısı. Geniş Açı 2010; 52-57.

30. Silva $C D$, at el. Social representation of domestic violence against women among nursing technicians and community agents. Rev Esc Enferm USP 2015; 49(1): 22-29. 